\title{
Interaction and Innovation - Reframing Innovation Activities for a Matrix Organization
}

\author{
Martti Mäkimattila, Minna Saunila, and Juho Salminen \\ Lappeenranta University of Technology, \\ Lahti School of Innovation, Lahti, Finland
}

\section{martti.makimattila@lut.fi; minna.saunila@lut.fi; juho.salminen@lut.fi}

\begin{abstract}
In this article we point out the importance of reframing and orchestrating an innovation process while adopting a matrix organization (MO) structure. Some studies implicate that a MO gives the flexibility desired and supports sharing of information and efficient use of resources in an organization. However, the MO is also a target of hard criticism by real life operational actors in organizations performing daily tasks. To find out reasons behind this gap, we studied the transformation phase of an organization from a line organization to a $\mathrm{MO}$ while simultaneously participating in innovation process development. The assumption was that collaboration with a motivated firm developing innovation activities and simultaneously adopting a MO gives exceptional insight into analyzing the change in a practical manner. Understanding the interplay between the organizational change and innovation activities is the key to success in today's pace of change in the dynamic business environment. Our case study was done in the field of media, which is one of the most challenging due the external systemic change of technology and consumer habits. To survive and compete in business, firms adjust their organizational designs and processes to gain innovations and to connect external innovation sources. Our study shows that different phases of the innovation process need different types of management and support from the organization. Organizations under constant change have to update their innovation process management to match their organizational designs.
\end{abstract}

Keywords: Innovation; Innovation process; Matrix organization; Organization design, Case study

\section{Introduction}

Many firms have adopted a matrix organization (MO) structure to utilize the firm's knowledge

Material published as part of this publication, either on-line or in print, is copyrighted by the Informing Science Institute. Permission to make digital or paper copy of part or all of these works for personal or classroom use is granted without fee provided that the copies are not made or distributed for profit or commercial advantage AND that copies 1) bear this notice in full and 2) give the full citation on the first page. It is permissible to abstract these works so long as credit is given. To copy in all other cases or to republish or to post on a server or to redistribute to lists requires specific permission and payment of a fee. Contact Publisher@InformingScience.org to request redistribution permission. and resources across the firm activities. Changing to $\mathrm{MO}$ has been in fashion in the last few years, but the theories have their roots way back in the 60s and 70s. It has been claimed that $\mathrm{MO}$ is flexible and supports innovation (Galbraith, 1971; Van der Panne, Van Beers \& Kleinknecht, 2003). Finding the right organizational form is about balancing between different needs, requirements to be fulfilled, and resources available. A 
Interaction and Innovation - Reframing Innovation Activities for a Matrix Organization

functional line organization has its benefits in the basic production environment, while different forms of matrix, project and team organizations can support new product development processes with their known strengths (Galbraith, 1971; Hobday, 2000; Liker, 2004; Smedlund, 2009). Interaction and openness, intra- and inter-organizational, are important levers to gain innovations in today's systemic, networked, and fast-paced world (Chesbrough, 2003; Johannessen, 2009). If a matrix is launched to support this, also adjusting and reframing the innovation process is a necessary task for successful activities and to gain the maximum benefit from it.

Based on an extensive search of current literature, there is a certain research gap in focused studies interconnecting the innovation process and adoption of a MO. Moreover, some recent studies drawing on matrix structure findings have suggested more research to be done on management interlinked to groups that steer and control innovation activities based on interaction (see e.g. Artto, Kulvik, Poskela, \& Turkulainen, 2011). The general interest in innovation and organization design research is increasingly heading towards complex interrelationships in dynamic contexts. In practice, managers are trying to merge processes and organizational structures in turbulent business environments. Studies rarely examine the facilitation and focus on innovation activities when firms are adopting a MO. The current study aims to address this research gap. The research question is: How to reframe innovation activities when adopting a MO?

The paper is structured as follows. Based on the theories of innovation processes and organizational designs, we build a case study using several research tools. This paper discusses interaction mechanisms of innovation and organization as well as analyzes the innovation process in a recently adopted MO. We describe the dynamic nature of the innovation process and organizational constructs. We also make visible the organizational challenges in the sub-phases of the innovation process. Finally, this paper concludes our research, its theoretical contribution and gives some managerial suggestions for changing the organization design and developing processes aiming to build an innovative organization.

\section{Literature Review}

\section{Innovation and Organizational Design}

Organizations' ability to continuously generate innovations is one of the key capabilities in today's business environment (Alegre \& Chiva, 2008; Bessant, 2003; Ellonen, Blomqvist, \& Puumalainen, 2008), and organizational designs are important part of enabling successful innovation activities (Miles, Snow, Fjeldstad, \& Miles, 2010). Organizational innovations are seen to enable innovation capabilities for better firm performance (Camisón \& Villar- López, 2014), and research on the organization of innovation projects suggests that project flexibility is a common reaction to technological turbulence (Candi, Van den Ende, \& Gemser, 2013). Flexible and consistently adjusting organizations are seen to outperform others especially in unstable and turbulent environments (Haveman, 1994). The overall practical implication based on Prajogo and Ahmed (2006) is that to achieve high innovation performance, organizations first need to develop the behavioral and cultural context and practices for innovation. According to Prajogo and Ahmed, only within such conducive environments is it possible for organizations to develop innovative capacity to deliver innovation outcomes and performance more effectively. However, it still needs to be further studied how this could be simultaneously connected to practical development of innovation processes and continuously changing future adaptive organizations.

According to Van der Panne et al. (2003), empirical studies show that successful innovative firms are loosely structured in the early phase of the innovation process and develop more formal structures in the later stages of the development process, and organically organized firms develop essential capabilities needed in innovation activities. Zaltman, Duncan, and Holbek (1973) also de- 
scribe how an organic structure is appropriate for the initiation stage and a mechanistic structure is appropriate for implementation. However, it seems that the literature cannot fully cover the challenges of such dynamics related to innovation structures and interaction with the continuous organization design changes that are commonly present in the current business world. Miles et al. (2010) write that traditional organizational designs (U-form, M-Form, Matrix, Multi-firm Network) will not be able to respond effectively to the opportunities and challenges faced by the 21 st century. New organizational designs that can mobilize large sets of actors who have the ability to self-organize and collaborate are needed. Fjeldstad, Snow, Miles, and Lettl (2012, p. 739) propose that these "new successful organization designs are based on an actor-oriented architectural scheme composed of three main elements: (1) actors who have the capabilities and values to selforganize, (2) commons where the actors accumulate and share resources, and (3) protocols, processes, and infrastructures that enable multi-actor collaboration." It is seen that the locus of control and coordination is the organizational actors themselves and their dynamically evolving networks and interdependencies related. According to Dougherty (2008, p. 430), "Social constraints are necessary because the work must be orchestrated, shaped, defined, and guided so that people can come together readily even if they do not know each other, can share key assets with others effectively, and can deal with the inevitable institutional pressures from regulators, competitors, and other social forces. Social actions are also necessary because innovation problems are unpredictable: people must improvise together in the situation since they cannot be told what to do ahead of time. Managers cannot force action and they cannot avoid constraint, so they need to constrain the organization to enable action." The aspects above are relevant when developing structures and processes that the firm uses to arrange tangible and intangible resources for intra and inter-organizational collaboration.

Artto et al. (2011) found that the organizational arrangements for innovations tend to rely on organic and embedded matrix structures and especially on the front end of innovation, emphasizing a wider set of embedded organizational arrangements than mere development groups - including personalized and value-based interactions between the executives and the staff, innovation processes and idea management, and innovation software systems. Another interesting finding was that innovation groups can be formal or informal organizational bodies in a matrix structure, circulating part-time representatives from lines in their roles, and with organic and ever-changing procedures (Artto et al., 2011). They also found there to be a clear distinction between the group roles for fostering and generating new ideas (often called innovation groups, consisting of staff members) and groups for selecting and transforming ideas into innovations (often called development groups or boards, consisting of middle managers). Based on their empirical study about the front end of innovation, Artto et al. see that innovation development groups should have representatives from "line" organization units when selecting, processing and advancing companywide innovation projects. In this way, a sort of a matrix structure in an innovation group ensures the involvement of all units through evaluation, decision making, and resourcing as well as information distribution in an organization. Some successful innovation processes, such as the DARPA (Defense Advanced Research Projects Agency) model, lean on a strong project manager in the organization, his vision and motives, given resources, and prior social networks while communication and control structures are evolving based on project progression (Carleton, 2010). Tushman, Smith, Woody, Westermanz, and O'Reilly (2010) found in their research that ambidextrous organization designs (coupling high structural differentiation with targeted structural linkage and senior team integration) are relatively more effective in executing innovation streams than functional, cross-functional, and spinout designs. They also point out the role of senior team integration with capabilities simultaneously explore and exploit in innovation activities.

Most of the existing innovation literature can be broadly classified as a technically oriented "process" approach and an organizational design oriented "structural" approach, although recently the cultural aspects of organizations supporting innovation strategies and the enhancing of 
Interaction and Innovation - Reframing Innovation Activities for a Matrix Organization

innovative capabilities have received more attention. Structural arrangements and process designs are considered rational approaches to integrate organizational systems and members, but often they are claimed to be ineffective because these changes are not synchronized with the existing values, attitudes and interests (Muthusamy, 2009; Nesheim, 2011; Porter, Lawler, \& Hackman, 1975). As addressed in books related to organization design, some sort of hierarchy and structures are always present, and often some sort of grouping as well. Grouping is often done based on skills (knowledge), process and function, time, output (products), markets (client) or place to be able to coordinate work in organizations (Mintzberg, 1983). Mintzberg (1983) also describes the decision making power in vertical and horizontal decentralization: "By using matrix structure, the organization avoids choosing one basis of grouping over another, instead it chooses both. It is dual authority structure which sacrifices the principle of unity command." Thus, a matrix can be seen as one possible solution for an organizational design challenge when aiming to adjust innovation activities for survival in turbulent environments.

\section{Matrix Organization}

The term matrix refers to a cross-functional organization that brings people together from separated organizational areas to undertake tasks on a relatively permanent basis compared to rather temporal project teams (Ford \& Randolph, 1992). Hobday (2000) delivers the matrix partition also into functional, balanced, and project matrices in project-based organizations. Nesheim (2011) approaches the matrix from a horizontal process management aspect with hierarchical line organizations. The MO grows out of the organizational choice between project and functional forms (Galbraith, 1971; Mee, 1964). Matrix management can provide "horizontal" coordination over "vertical" functional departments (Burns \& Wholey, 1993). The matrix is a hybrid structure with two or more distinct hierarchies, often seen as customer-facing units obtaining resources from a functional dimension (Fjeldstad et al., 2012). A matrix assembles skills and resources across as well as up and down the hierarchy with coordination and control built in. A matrix design seeks to capture both the efficiency and specialization of the U-form (unitary) and the customer focus and flexibility of the M-Form (multi-divisional) (see Miles et al., 2010). There are various forms of matrix structures among other organizational arrangements. Hobday (2000) describes the different types while presenting the alternatives, from functional forms to project organizations and matrix forms associated with and between them.

It is claimed that a matrix improves communication and can handle increased information loads when compared to the more traditional functional structures. Forced contacts and communication over departments are improving decisions making and response time, which translates into an organization that can quickly and flexibly adapt to a dynamic situation. It is, however, also recognized that split or shared authority and responsibility between boundaries creates conflicts in resources, interests and assets (Davis \& Lawrence, 1977; Ford \& Randolph, 1992).

Ford and Randolph (1992) write that an organization cannot plug a matrix into its existing structures and expect success, and Davis and Lawrence (1977) warn that a successful matrix must be grown instead of installed. Burns and Wholey (1993) studied the adoption and abandonment of matrix management in organizations from organizational information processing (in terms of information that must be gathered, interpreted, synthesized, and coordinated in the context of decision making) and inter-organizational network basis. According to them implementing a matrix structure constitutes a shift from vertical- functional authority toward a hybrid, function-byproject organization. Matrix structures are seen as team-oriented arrangements that promote coordinated, multidisciplinary activity across functional areas, broad participation in decisions, and the sharing of knowledge. Burns and Wholey (1993) also point out that research on the adoption of matrix management may improve understanding of factors favoring structures that promote product innovation and quality management (like continues improvements). Their research results 
also suggest that "organizational networks influence the diffusion of administrative innovations in much the same way that they influence the spread of technological innovations" (Burns \& Wholey, 1993, p. 130). Saunila, Mäkimattila and Salminen (2014) state that a matrix structure alone cannot solve all the challenges related to innovation activities, and the transformation towards a matrix structure requires time, employee commitment, and management.

\section{Research Design}

Starting from MO literature supplemented with innovation studies, we searched for a case that could provide us empirical evidence on a practical level. An organization with several units and strong customer and production dimensions in a turbulent environment was found in the media business.

\section{The Case Organization in Fuzzy Media Markets}

Media is one of the most challenging and rapidly changing business areas today (Campos, 2009; WAN-IFRA, 2009). The environment has been affected by globalization, and new technological innovations and user demands need to be taken into account in new media services. The development of IT, internet, social media, etc. has changed the whole operation field, the media, customer, and audience relationships. To respond to the change and future needs, news media companies must shift their organizations to focus on their audiences, not on the old ways of producing and doing business inside specific silos (Campos, 2009). Media used to be driven by a very traditional functional process of producing daily news on paper for committed consumers of a chosen publication. Its daily routines and organization were formed for that purpose, but the world changed around and new needs emerged that needed to be satisfied. The challenge of interconnected media and consumer habits demands new approaches, daily renewal of products, and services and organizational forms answering to these needs. The new agile product development process is shifting structures towards matrix and project organizations, as mentioned in many previous studies (Hobday, 2000). A media firm's organization and innovation process has to be able to answer in different lengths of cycles of innovating daily content for consumers (readers and listeners) and customers such as advertisers, and a bit longer cycle of new innovative service platforms and products developed for survival over a longer time frame. The pace and interval are different within these cycles, which also challenges the leadership of innovation and resource management (Halbesleben, Novicevic, Harvey, \& Buckley, 2003; Pérez-Nordtvedt, Payne, Short, \& Kedia, 2008).

Media firms are traditionally seen to be operating in oligopolistic and monopolistic markets with lower levels of competition than found in many other industries - and some managers do not have an experience or knowledge base of how to operate in rapidly changing markets (Picard, 2004). Media companies have been adjusting strategies while trying to compete with other firms and innovations launched by them. There exist links between changes and business opportunities, suggesting systemic interplay within innovation activities. "Management theory dictates that organization must follow firm's strategy - and strategy depends on vision of the company, its capabilities and resources, the markets and the competition - so the organizational model should be the best suitable for company's purposes" (Campos, 2009).

The data used in this case study was collected from a private organization specializing in various areas of media business. The case organization was a media company located in southern Finland, regionally seen as a very important actor. It has several business units that have different roles in the organization with shared and their own functions. This includes several printed papers, internet services, radio, and traditional supportive units such as printing, distribution, and functions such as IT and administration. Altogether there are around 270 employees in the organization. This organization, like its competitors in the media business, is balancing between traditional and 
new media and struggles with the common challenges in the rapidly changing business environment. They have understood that innovations are needed for renewal and future business success while cutting costs is not enough for survival and profit making. Previously there have been some attempts to develop innovation activities, such as the use of an IT-based idea gathering system, but the results were considered inadequate and the system implemented did not achieve a satisfactory level of use. Units partly competing with each other did not fully support positive interaction for idea refining and execution of innovations. The firm's collaboration goal with university was to utilize practice-based innovation by increasing theoretical innovation knowledge in the organization and to simultaneously harness the hidden innovation potential for business with precise analysis and implemented designs for a recently released supportive MO. During 2009-2011, collaborative actions (Figure 1) took place to describe how ideas need to be managed to become beneficial innovations and how to prepare the organization to utilize external innovation better in other words, the organization needs to be internally open so that it can also be externally open for innovation activities.

\section{Research Methods}

The methods used in this study are a combination of action oriented research (Coughlan \& Coghlan, 2002) and case study research methods (Eisenhardt, 1989; Flyvbjerg 2006; Voss, Tsikriktsis, \& Frohlich, 2002; Yin, 1994). According to Coughlan and Coghlan (2002), action research uses a scientific approach to study important social or organizational issues together with those who experience these issues directly. Action research always has two goals - making the action happen and reflecting on what happens - in order to contribute to the theory. This process involves collaboration between the researchers and members of the organizational system. Action researchers are not just observing change; they are actively working to make it happen (Coughlan \& Coghlan, 2002). An action research project provides the context of this study, see Figure 1. A visible result was an innovation handbook, describing the routes and actors involved from idea refining to innovation in a fresh MO (see Salminen, Saunila, \& Mäkimattila, 2011 for further details). The concept is about enabling actors, commons, and protocols to self-organize better and having updated descriptions for senior / top management about the innovation process itself and a window to support idea gathering and the progression of innovations. The method and tools used are not limited to a MO, and the whole handbook development process can be seen as data acquisition and analysis of organization design and related challenges.

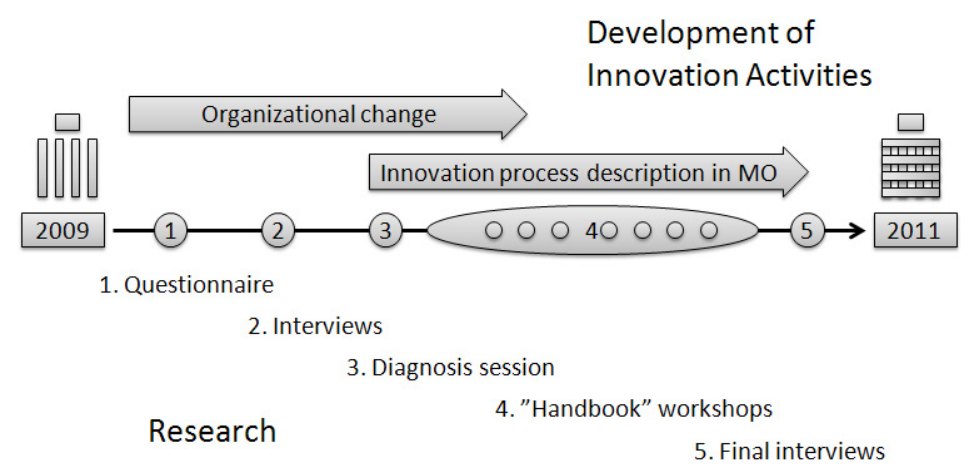

Figure 1. Action oriented research tasks related to development activities

The focus of the study is on the organizational level, but as has been found in literature, other levels of nested issues and timing should also be considered, e.g., process studies explaining development and change in organizations, like by Van de Ven \& Poole (1995), and a wide range of 
innovation studies (Teece, 1996; Teece, Pisano \& Shuen, 1997) focusing on the level of organizational actions also pay attention to the roles of individuals and industry specific issues. This study approaches the combination of organizational design and the innovation process as an interlinked entity which requires a deep understanding of individuals, the organization, and industry specific details. Complex relationships require several data acquisition methods, a rather long surveillance period, and close collaboration with the organization under analysis.

A single case study was chosen to achieve a deep understanding of a multi-unit organization under dynamic change and organizational response over borders. Several methods of data collection and multiple researchers were used to gain triangulation and ensure results (Eisenhardt, 1989; Flyvbjerg, 2006; Pålshaugen, 2009; Voss et al., 2002; Yin, 1994). The research included five main phases of information gathering and was made simultaneously with the strategic development process in corporation. Those five stages were the following: 1) a web-questionnaire for everyone in the organization, 2) interviews of chosen employees, 3) a diagnosis session with managers and key persons, 4) Innovation handbook workshops, and 5) a final interview with the firm's key personnel participating in the development process, see Table 1 . The study was carried out in 2009-2011 by four researchers gathering and analyzing data. The findings are a result of the shared interpretations of researchers based on information achieved with the various data collections methods presented here.

\section{Table 1. Summary of the data utilized in study}

\begin{tabular}{|l|l|l|l|}
\hline Data & $\begin{array}{l}\text { Number of } \\
\text { people involved }\end{array}$ & Purpose & Output \\
\hline $\begin{array}{l}\text { Survey } \\
\text { (13 questions } \\
\text { based on in- } \\
\text { novation lit- } \\
\text { erature) }\end{array}$ & $\begin{array}{l}\text { All employees } \\
\text { of the case } \\
\text { company } \\
147 \text { (out of 270) } \\
\text { responses }\end{array}$ & $\begin{array}{l}\text { Diagnosing the current state in } \\
\text { innovation activities related to } \\
\text { personal and organizational } \\
\text { levels }\end{array}$ & $\begin{array}{l}\text { The questionnaire showed a clear } \\
\text { gap between felt importance and } \\
\text { realized actions taken in several } \\
\text { fields }\end{array}$ \\
\hline $\begin{array}{l}\text { Interview } \\
\text { (semi- } \\
\text { structured, } \\
\text { recorded and } \\
\text { transcribed) }\end{array}$ & $\begin{array}{l}15 \text { senior man- } \\
\text { agers and inno- } \\
\text { vation agents }\end{array}$ & $\begin{array}{l}\text { Diagnosing the current state of } \\
\text { the innovation process and } \\
\text { related activities }\end{array}$ & $\begin{array}{l}\text { Need for a clearly structured and } \\
\text { described innovation process, } \\
\text { challenges in organization design } \\
\text { for innovation activities }\end{array}$ \\
\hline $\begin{array}{l}\text { Diagnosis } \\
\text { session; } \\
\text { (summary } \\
\text { memo) }\end{array}$ & $\begin{array}{l}15 \text { senior man- } \\
\text { agers and inno- } \\
\text { vation agents } \\
5 \text { researchers }\end{array}$ & $\begin{array}{l}\text { Further developing the output } \\
\text { of the questionnaire and inter- } \\
\text { views. }\end{array}$ & $\begin{array}{l}\text { Development targets of the inno- } \\
\text { vation process and related activi- } \\
\text { ties }\end{array}$ \\
\hline $\begin{array}{l}7 \text { workshops, } \\
\text { (documented } \\
\text { with photos, } \\
\text { memos and } \\
\text { summaries) }\end{array}$ & $\begin{array}{l}3-6 \text { innovation } \\
\text { agents } \\
2-4 \text { researchers }\end{array}$ & $\begin{array}{l}\text { Creating an adaptive "innova- } \\
\text { tion process handbook", a } \\
\text { systematic procedure to search } \\
\text { and select ideas, accelerate } \\
\text { and launch them and also a } \\
\text { description of roles and re- } \\
\text { sources involved and links to } \\
\text { management }\end{array}$ & $\begin{array}{l}\text { Description of the innovation } \\
\text { process in the fresh matrix struc- } \\
\text { ture (self-organization in a man- } \\
\text { ageable manner) }\end{array}$ \\
\hline $\begin{array}{l}\text { Closing inter- } \\
\text { views, (semi- } \\
\text { structured, } \\
\text { taped and } \\
\text { transcribed) }\end{array}$ & $\begin{array}{l}6 \text { innovation } \\
\text { agents }\end{array}$ & $\begin{array}{l}\text { Clarifying the results and } \\
\text { benefits of the process done } \\
\text { and current activities going on } \\
\text { to carry outcomes further in } \\
\text { practice in the MO }\end{array}$ & $\begin{array}{l}\text { Issues in the current organiza- } \\
\text { tional design and development } \\
\text { targets for the future }\end{array}$ \\
\hline
\end{tabular}

1) A questionnaire related to the innovation process was targeted to all employees. 13 questions were formulated based on innovation literature (see the Appendix). The questionnaire aimed to 
Interaction and Innovation - Reframing Innovation Activities for a Matrix Organization

gain understanding on the current state of the chosen topics related to personal and organizational levels by asking both the perceived importance of the topics and their current situation in the organization. The results of the 147 responses were summarized and used as part of the diagnosis session. The questionnaire showed a clear gap between the felt importance and realized actions taken in several fields. The questionnaire was also analyzed to understand the form of innovation management in the case company for development activities and to create a basis for further, more detailed interviews.

2) Interviews were conducted with senior managers and key professionals. The interviewees included persons in every operation of the matrix, held responsible for innovation activities in their own area. The interviewed senior managers acted as their supervisors. 15 interviews in total were conducted, transcribed, and analyzed. Managers and key professionals were asked semistructured questions but also given ample space to provide their own perceptions on the topics. Typically such open-ended interviews lasted a bit over one to two hours and were conducted in a timeframe of one month, during a corresponding stage of process and organizational change in the case company. The frame of the semi-structured interview was built on a) personal role in innovation activities, $b$ ) practical collaboration in the organization, c) innovation structures and processes, d) leadership and management-related innovation activities, e) customer and other external information in networked innovation, $f$ ) efficiency and measurement of innovation activities in the organization. Each theme had 5-10 preplanned supportive assisting questions which were used according to the flow of the interviews as they progressed.

3) A diagnosis session was used as a method of interpreting previously gathered information (1-2) with the chosen employees and managers of the case company to add and complement current common knowledge with available information for future use. The majority of the participants also took part in the interviews. The target was to share information and findings within the organization and to enhance essential information by participating. A summary memorandum was written based on the findings in stages 1-3 to be used as a basis for future innovation workshops. Furthermore, the findings presented in the memorandum were circulated and approved by the participating researchers and the target organization's key persons.

4) Innovation workshops were organized as thematically oriented sessions, based on data gathered and analyzed earlier (1-3). Five main themes were covered in the sessions: a) innovation management and roles in the organization, b) the innovation process - from opportunity recognition to idea refinement and solutions, c) developing innovation activities, $d$ ) personal innovation capabilities, e) measurement of innovation activities and continuous innovation system evaluation. The participants were chosen by the case company with the criteria of "development-minded key persons from different units". The meetings were structured and scheduled within a time frame of one year in the form of 7 half-day workshops (described in more detail in Salminen et al., 2011). The aim of the workshops was to create "an innovation process handbook", a description of roles and resources interlinked to the systematic process to search and select ideas and develop them to innovations. The Innovation Handbook was designed to be used during the development project to document outcomes and communicate the results also to the upper management to gain their simultaneous acceptance. Later it will be updated according to future needs by the "innovation agent" group. It is important to note that one main aim was to create a collaborative platform for interaction over unit borderlines. Action-oriented research was conducted during this process and all sessions were documented.

5) Finally, workshop participants were interviewed again in spring 2011 to clarify the results and benefits of the process done and current activities going on to carry outcomes further in practice in a MO. A semi-structured frame was built on the following themes: a) the "innovation handbook" process and the interactive platform used for its creation, b) organization structure 
changes, c) innovation knowledge and capability development, d) development action benefits and inertial issues.

\section{Analysis and Findings}

We found several main issues to focus on when developing innovation activities and orchestrating them in the fresh MO. The main findings (in research phases 1-5 and their analysis) are presented and integrated under the following topics from all the phases of the research and analysis: (1) Sharing resources and managing them, (2) A visible innovation process and clear channels for ideas to evolve, and (3) Internal and external brokerage, breaking boundaries with key individuals.

\section{Sharing Resources and Managing Them}

One major challenge during the change period from a functional organization to a MO needs to be stressed. In the diagnosis session, there was a debate about existing development resources, such as money and workforce, and the owner of the idea for future actions. There was an argument over whether the needed resources are already allocated on a unit, profit center, or corporate level, because the organization was also changed to a matrix recently. The corporate level opinion was that development budgets are in units. It was interesting that business units said that the R\&D money was only for previously known projects in the budget and there was no money for corporate level innovation activities. There were no resources seen to be allocated for shared innovation projects. This was actually a quite natural outcome of an issue related to shared resources, but one that is very important to notice during a change period. Our case firm handled this discussion in a very innovative and positive manner, even having some great ideas of rewarding risk takers willing to allocate resources for common projects in the future.

It is very easy to describe the general level of how the information flows in a matrix, but when asked which persons are needed to participate and make decisions in the organization, it was seen that the routes were not clear and they had to be clarified. Common practice was that to push ideas forward, you go talk to top management with power to make things happen. It was also mentioned that decision making was distributed between different isles, and it was seen to be only partially optimal when orders were given. An interesting outcome was that instead of breaking silos, people felt that transferring to a matrix could actually force boundaries and build new walls in new directions. A practical forum for collecting ideas was missing, and the plans were seen too abstract or missing for real interaction to take place. The matrix structure was also easily seen to disturb the daily work and to cause confusion.

"When you adopt a matrix organization, everyone would like to be developers of functions, but no one wants to focus on the daily operative routines. It is very nice to present ideas about everything, as long as you don't have to participate in 'executing' those," said one manager in the organization.

The conclusion was that people were trying to perform the daily tasks without being able to gain the real benefit from the matrix structure. Learning takes time, and there is always inertia present when adopting new ways. The problem of "free riding" was also mentioned several times. Units are not willing to put efforts and resources into development activities if they think someone else in the organization will do those anyway soon enough. It is a way of saving one's own resources for other issues with a quicker pay back, better profit, or projects including less risk. The organization will be slower to respond to challenges and even sometimes miss the opportunity window for business.

To be able to utilize the benefits of a matrix, a group of Innovation Agents was formed. Their task is to update the documented descriptions of processes and resources related to innovation activi- 
Interaction and Innovation - Reframing Innovation Activities for a Matrix Organization

ties in the organization. They also catalyze and support related actions and form an integrative forum over operational unit borders in the matrix. This group helps to choose the right ideas for refinement and acts like a godparent for innovation, ensuring its resources and progress. The agents' role is not to be project managers, but instead they build fertile ground for ideas to mature and link innovations to strategy and support management. Firm strategy should have an impact on the ideas and innovations generated, but strategy should also be updated based on good innovations. One major issue is to share the knowledge that innovation activities are based on and build trust between actors to enable innovations.

In the interviews, intellectual property issues were not mentioned to cause problems, except complicated copyright laws in the media field, especially in multimedia content production. Despite this, a major issue was that people were worried about other departments and units stealing ideas from the original inventor. This concern was more related to competition between units than between persons. The outcomes are related to the current economic pressure to make arrangements to cut costs in weakly performing units and functions. People were motivated to see their own ideas develop into something concrete; other rewards were seen more as something extra. The conclusion was that clear rules for departmental IP actions inside the corporation are essential to avoid this cause of inertia and to increase openness. There was also a recognized need to build trust through interaction and shared resources. Building up trust requires time and action (Blomqvist, 2002; Ellonen et al., 2008). "Earlier units wanted to keep their own issues and ideas to themselves. And we did not tell those to others... I think we have been able to get rid of that kind of attitude", it was said.

Enabling fast decisions and agile management is crucial for today's business. It is important that decisions are done routinely on a suitable level to avoid jamming the top level or finding unofficial routes to proceed. Everything being brought to the top is a phenomenon that seems to occur easily in a fresh matrix. The decision making process has to fit the needs of the organization and it cannot cause inertia and temporal problems. During the research period, it was noticed that the discussion focused first on the firm's matrix structure and later it changed towards building internal capabilities to utilize external resources in an efficient manner. The matrix was left out of the discussion as the development project proceeded and became focused on "the right people in interaction".

\section{A Visible Innovation Process and Clear Channels for Ideas to Evolve}

"Often you hear the question of where to present this idea and to whom..." "Sometimes ideas are processed until the final stage in units, without thinking what it means to others". "...as described in the handbook, we really need systematic project management and professionals ... if it is done as a side job, the results are what they are."

Creating ideas and accelerating and launching them require a systematic process and paths to take information forward and to make decisions. Decisions without real life resources and commitment are a waste of time; this is a major issue especially in matrix operations. There has to be certain interplay and respiration throughout the processes and the internal MO, and also out of the corporation to gain new inputs for future innovations. Insight and action inertia matters in different phases of the innovation process (Godkin, 2010). A certain level of continuous change is desirable to avoid lock-ins and silos in the organization. Focused resources are essential for a clear process, and ownership of innovation is important.

The creation of the handbook was seen as a successful way to find time for development and take concrete issues forward and make them visible. "It can be clearly seen what everyone's role is in every stage, where they can get support, where to address issues and who is deciding and what. 
Generally the guidelines and documents for positioning issues in the organization are a very important aspect. And how to bring things forward in the organization... how to coordinate those, it is big thing..." It was also mentioned that "all groups have not understood their responsibilities and roles in innovation activities and the need to serve the whole matrix, they are still working like they did in the past, and they are not able to gain the benefit from the matrix structure..." In sum, the description of the innovation process in the matrix was seen as important.

"I think that it helped to simply have different clear phases described. Planning projects is much easier and I know in which stage we are going, I can define how ready the issues have to be in every stage".

The description of the innovation process over the unit limits in the corporation was seen as very useful. The "handbook" mapped how the information flows and resources are involved. Too many times there are attempts to solve these issues with implementation of IT systems and thinking that they will solve the problem. Our study suggests that they might be good support, but enabling interaction and clarifying the information flows related to actions are keys to success. It is very important to have a common understanding in the organization regarding which activities are worth of lifting to the corporate level and which are continuous improvements in units (Figure 2 ). There is a difference between knowledge sharing and building - some best practices can be transferred but some have to be developed together. We found out that the matrix is expected to take care of this issue, but it seems that the matrix is simply one of the enablers when the innovation process and its relationships are described well. A clear description of the process and its acceptance by top management prevents internal arguments over responsibilities. It is clearly a commonly shared model of how to proceed with things.

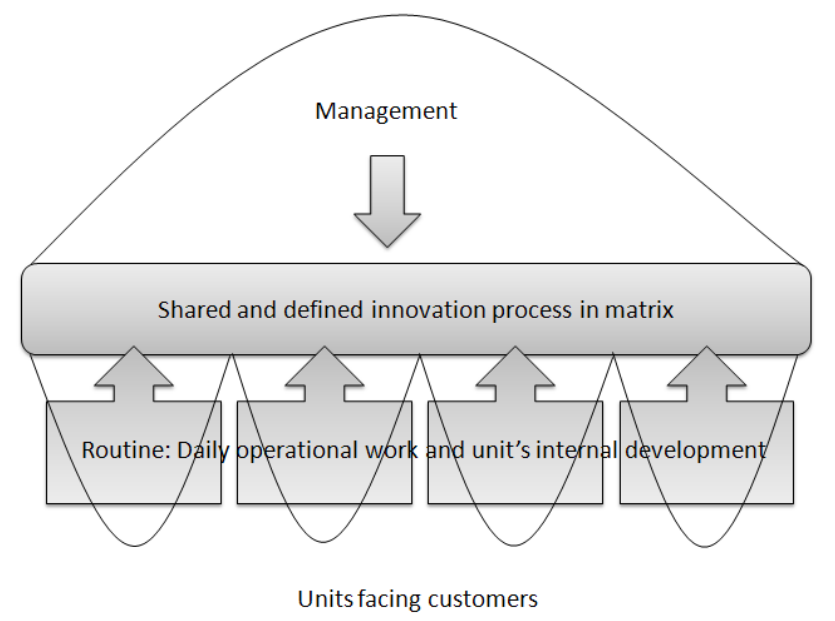

Figure 2. A collaboratively agreed process to get senior management and employees pursue innovation - description of the process and actors in the Handbook of Innovation

"I think it is clear that we have the godparent for an idea, the owner of the idea, or not maybe the owner but someone responsible for carrying the idea further... a responsible person to keep up with the development and schedules, I think it ensures that something happens".

"I think nowadays different aspects, like marketing, are better noticed and considered. I do not know if it is about the handbook and process development or purely due to the matrix or other reasons, but the interaction is better than before".

There was a clear demand for a forum and for members to represent different units and functions to develop the innovation process and evaluate the ideas into a concept for projects (see Figure 2). 
Interaction and Innovation - Reframing Innovation Activities for a Matrix Organization

The innovation agents took this position in our case company. They built up the capabilities for innovation actions by actively participating in the fuzzy front end of the innovation process.

Informal ways appearing for information flows are good indicators of process success and of the existence of an organization map. It indicates whether routing or resourcing should be updated to a certain extent or if implementation and learning of new arrangements need more attention. One of the interviewed persons had a rather expecting opinion of the implementation: "process development was good, but the real change is still waiting..."

In most industrial firms, R\&D processes are described (e.g., Cooper, 1990, 1993) due to quality certifications and company policies, but the process reaches the fuzzy front end of innovation surprisingly seldom. In other fields, such as the media, the focus has been in processes of delivering news and development processes are rarely clear. Even if the firms have created some sort of clear path for innovation processing or systematic use of interpretative methods, it is very seldom updated when the organization form is changed or if the firm is facing a merger or acquisition. A clear description is also very useful when new employees are orientated for their tasks in order to be part of creating the firm's future success through innovations. Based on workshops with our case firm, we also had a clear need for description improvements in the fuzzy front end of innovation, and also in describing the process and resources for innovation execution activities. The firm's prior process focus was mainly on producing daily news inside units.

\section{Internal and External Brokerage, Breaking Boundaries with Key Individuals}

Internal and external brokerage (Burt, 2004; Parjanen, Harmaakorpi, \& Frantsi, 2010) was needed to support development activities. External brokerage supported internal communication, made visible the need of internal interaction platforms and brokerage, as well as showed the potential of external sources of innovation and the need of internal capability development to utilize those. In interviews it was pointed out that during development activities an external broker can undress the command chain and hierarchy to enable information flows over existing vertical and horizontal borders.

"If the unit director says that today we develop the process together, in reality it means that the direction of discussion goes by his goals and thoughts, and then starts the blocking, etc. Outsider attendance gives fresh thoughts and questions, sort of external views and releases the thoughts of the group, because they do not have to be responsible for their thoughts to their boss who is sitting nearby... We can direct opinions to an outsider and say why it can be done like this or like that."

The importance of linking theory and practice was mentioned several times as very useful. "It was very important that a third party was framing and supporting the development work; the process model would not have formed internally... theoretical background gives more insight..." Also finding time for development was easier with planned external meetings: "...in our daily rush we do not have time to think about these issues, but with preplanned external meetings in the calendar we were able to use the time to think and develop the process, and we found lot of good points. Especially the role of the Innovation Agent -group was clarified, what it is and should be..." "Actual collaborative doing and developing was welding this group together".

As a result of the diagnosis and interviews, it was easy to agree that the case firm could benefit from an internal team supporting the innovation process in the organization. The team was focusing on describing the innovation process in a new MO, updating it and supporting the fuzzy front end of innovation activities with agreed tasks. External brokerage reduced inertia while developing the innovation process and knowledge sharing. The process description was a theory-based learning process for the participants about the relationships and interplay in innovation, not only 
to produce a road map or flow chart for the Innovation Handbook. Team members were chosen from different units and with the right active development attitude. These innovation agents were first to break the silos through interaction and build up the common interest of innovation activities with the support of the innovation director. Internal agents are in a key role and their task in the innovation process has to be clearly defined, and management commitment is crucial.

\section{Discussion}

Based on our study, we are convinced that different phases of the innovation process have different characteristics and needs regarding the organization. The early phase should be supported by exploring future oriented information (Uotila, Mäkimattila, Harmaakorpi, \& Melkas, 2011), idea generation handled with a fuzzy and not too forced manner, the concept phase should be driven by the organization seeing alternatives and the common goal, and the project development phase should have clear execution steps and resources (see Candi et al., 2013; Cooper, 1990). The management has different expectations and needs in different phases. Because of today's efficiency pressure, it is easy to focus only on visible actions and quick rewards, which easily cuts other efforts than clearly targeted and measured. The organization should be able to use resources also in the early phase of innovation and to have the flexibility to find the right individuals with interest and knowledge (Chesbrough, 2003; Fjeldstad et al., 2012; Huston \& Sakkab, 2006). The challenge is to let the organization adjust based on developed innovation and adapt to the needs of current stages. This should be done simultaneously while sharing resources with the daily operational challenge of business activities - creating income for the firm to finance innovations to become future "milked cash cows". The impression based on the results is that if the organization is purely focused on functions and current products, it can mainly develop incremental innovations (see Tidd, Bessant \& Pavitt, 2005) of current products and processes. If the organization is closer to a project form, radical innovations (see Augsdörfer, Bessant, Möselin, Stamm, \& Piller, 2013, pp. 17-20) emerge easier but development activities focus on certain projects and challenge the enduring elements of the organization. The matrix tries to combine the good features but has the pitfall of unclear responsibilities. The challenge is to find out how to ensure the flexibility and time for sourcing and refining ideas within a matrix while simultaneously having the internal and external pressure of efficiency. While the idea matures into a development project, the challenge changes to the capability to carry tasks and investments to a goal without dominating and stealing resources from other projects. This has to be done so efficiently that the opportunity window still exists for the product launched. We see these findings to be in line with pervious exploration and exploitation studies and their management balance discussion (March, 1991; Miles et al., 2010).

Organizational challenges in the different phases of the process are summarized in Table 2 to demonstrate practical implications to be considered in an organization's design and process development actions. 
Table 2. Main outcomes: the innovation process phase and MO challenges

\begin{tabular}{|c|c|c|}
\hline Phase of innovation process & $\begin{array}{l}\text { Challenge in the organization, } \\
\text { previously or due to the change }\end{array}$ & Action in MO \\
\hline $\begin{array}{l}\text { Signals and opportunity recogni- } \\
\text { tion }\end{array}$ & $\begin{array}{l}\text { Passive, only some active and } \\
\text { focusing on own field of exper- } \\
\text { tise, not seen as a part of every- } \\
\text { one job }\end{array}$ & $\begin{array}{l}\text { Interaction platforms and training } \\
\text { for absorptive capacity - every- } \\
\text { one jobs to acquire and share } \\
\text { cross functional information }\end{array}$ \\
\hline Idea generation & $\begin{array}{l}\text { Employee participation and moti- } \\
\text { vation on an average level. Ideas } \\
\text { not shared due to competition } \\
\text { between units. }\end{array}$ & $\begin{array}{l}\text { A common platform for common } \\
\text { good, all units participating in } \\
\text { idea refinement, motivation and a } \\
\text { supportive culture }\end{array}$ \\
\hline Idea evaluation & $\begin{array}{l}\text { No clear forum internally and the } \\
\text { customer aspect biased }\end{array}$ & $\begin{array}{l}\text { Done systematically in a cross } \\
\text { functional team and linked to } \\
\text { strategy aspects and total cus- } \\
\text { tomer needs }\end{array}$ \\
\hline Refining to Concepts & $\begin{array}{l}\text { Partial picture of needs due lack } \\
\text { of communication }\end{array}$ & $\begin{array}{l}\text { Customer oriented products and } \\
\text { services supplementing each } \\
\text { other and every unit, platforms } \\
\text { for refining }\end{array}$ \\
\hline Decision to develop further & $\begin{array}{l}\text { Previously go / no go too early, } \\
\text { the available resources seen } \\
\text { mainly internally in a unit. } \\
\text { Change to the matrix has con- } \\
\text { fused decision paths and authori- } \\
\text { ties. }\end{array}$ & $\begin{array}{l}\text { A collaborative view of benefits } \\
\text { and available resources between } \\
\text { units and functions - also the } \\
\text { possibility / alternative to do only } \\
\text { in a unit, with partners or a suit- } \\
\text { able time period later }\end{array}$ \\
\hline Starting project & $\begin{array}{l}\text { Starting if / when resources avail- } \\
\text { able and often based on a per- } \\
\text { sonal hunch }\end{array}$ & $\begin{array}{l}\text { As soon as it looks profitable by } \\
\text { using internal or external re- } \\
\text { sources and costs considered }\end{array}$ \\
\hline Running R\&D project & $\begin{array}{l}\text { Often on the side of an opera- } \\
\text { tional rush in a unit - or totally } \\
\text { externally with loose control and } \\
\text { management due to internal } \\
\text { know-how }\end{array}$ & $\begin{array}{l}\text { Utilizing internal and external } \\
\text { resources better, clearly lead by a } \\
\text { strong PM in the matrix and a } \\
\text { follow up (time and costs) }\end{array}$ \\
\hline Testing & A partial view, function or unit & $\begin{array}{l}\text { The customer in focus, feedback } \\
\text { in the matrix }\end{array}$ \\
\hline Implementing & $\begin{array}{l}\text { A unit or function aspect, daily } \\
\text { operational priorities often first }\end{array}$ & $\begin{array}{l}\text { Entirety, attention to in-house } \\
\text { communication and internal sales } \\
\text { before external actions }\end{array}$ \\
\hline Measuring innovation process & $\begin{array}{l}\text { No clear indicators, projects con- } \\
\text { trolled with varying methods }\end{array}$ & $\begin{array}{l}\text { Defined indicators and monitor- } \\
\text { ing, tracked through the process }\end{array}$ \\
\hline Learning & $\begin{array}{l}\text { Poor loop, hard to learn when } \\
\text { processes are hardly repeatable } \\
\text { and no clear description and } \\
\text { documentation }\end{array}$ & $\begin{array}{l}\text { Innovation agents and an update- } \\
\text { able process description enables } \\
\text { learning, the focus also on docu- } \\
\text { mentation. The innovation direc- } \\
\text { tor with senior managers ensuring } \\
\text { the corporate aspect. }\end{array}$ \\
\hline
\end{tabular}

Our study suggested that firms should come to terms with very practical matters to reinforce their innovation activities and utilize capabilities. This means going back to the very basics, like having social interaction platforms to combine information and build trust over unit boundaries and knowing who makes the real decisions about the resources available for agile actions for common good. These findings are in line with Nesheim's (2011) paper, as well as with his notion that "The ability to develop arenas between process owners and the operative organization is vital." When 
previous information channels and decision making are rerouted for the matrix, it is very useful to have discussion platforms with visual descriptions of innovation paths in the organization. When old structures disappear, it is very easy to end up in a situation where workers lack the interest of pushing ideas through unclear paths while daily working and operational challenges are enough in the new organization form. The aimed benefits of a MO might be overruled not only because of the internal political games usually blamed, but also because of unclear routes for real life information and operational decisions. There have to be efficient ways of connecting senior level managers (as in a matrix) with their formal authority to make decisions and support planned actions (see Artto et al., 2011; Nesheim, 2011). Allowing personnel (from different vertical and horizontal positions) to describe flexible and updateable processes including linkages to the senior / top management for total business optimization might be one solution. Such an "innovation agent group" could combine people and their activities in a matrix, develop the innovation process, foster and generate new ideas, select and transform ideas into innovations - instead of doing these within separate teams (see e.g., Artto et al., 2011). The group is able, to some extent, to circulate individuals and also utilize their social networks inside and outside the organization to advance innovation activities. The above mentioned aspects also support the behavioral and cultural context to achieve high innovation performance (Prajogo \& Ahmed, 2006).

Our study confirms the result of Artto et al. (2011) that the natural development path of an innovation organization begins with emphasizing diagnostic and boundary systems, followed by a more intense focus on interaction to find a common meaning and justification for the shared innovation activities. Based on our study, we can say that if the firm can really describe together over its unit boundaries how idea generation is catalyzed, innovations developed, and actions taken in projects, it is on the correct path. These findings are well in line with the recent study of Artto et al. (2011), stating that there are several integrated management control mechanisms for innovation activities embedded in organization structures. Our case also provides evidence for the argument of Artto et al. (2011, p. 416) that IT systems are often used to store information, but without any other interaction they are more likely to increase the social distance between individuals than facilitate innovation collaboration in the organization. Interaction is needed to build common interest and motivation to gain resources to push innovation forward. One of the challenges is to define what the difference between daily continuous improvements and innovations in units is and which ideas have to be lifted to a shared platform with other units (see Figure 2). Employee driven innovation can be seen as much more than employees just having ideas (Kesting \& Ulhøi, 2010; Salminen et al., 2011). This is a key issue in order to achieve the necessary agility and decisions and to avoid internal inertia. To be able to play on a field of systemic innovation, practical shop floor knowledge that is usually seen as a source of incremental innovations has to be connected to information often claimed to be in decentralized R\&D units and leading towards radical innovations. We agree that today's challenge is to connect all available information and transform it into practical agile actions with situational awareness (Sonnenwald \& Pierce, 2000) provided in collaborative networks of actors from all organizational levels (Fjeldstad et al., 2012). Fjeldstad et al. (2012) have also aptly described organizations' aims towards capable actors that self-organize and share resources with processes enabling multi-actor collaboration. In today's business, external and internal change is constant, so rather than find ultimate stationary solutions, we should find out how to predictably enable change and gain relative benefits from dynamics. This also fits the design of innovative organizations, especially in the world of discontinuous and disruptive innovations (see Augsdörfer et al., 2013). Due to the systemic nature of innovations, they also have a counter-impact on the organizations from which they originate creating a need for re-adjustments of the organization and triggering new innovations into the ecosystems. This is evident especially in media companies trying to adapt and innovate to survive. 
Interaction and Innovation - Reframing Innovation Activities for a Matrix Organization

To summarize, an important theoretical contribution of our research lies in the distinction made between organizational flexibility especially in the early stages and conceptualization of innovation, and in the later stages when focusing on performance and clear execution processes of evolving solutions. These findings include similarities with old organization studies related to innovation (e.g., Zaltman et al., 1973) as well as recent technological innovation studies (e.g., Candi et al., 2013) discussing internal and external turbulence interlinked to planning and specification flexibility. We would also like to highlight that the things required from the organization change during the innovation refinement from an idea to a product or service - an organization has to be able to meet both endogenous and exogenous innovation challenges. These issues are important when developing matrix or alternative organization structures to manage and support parallel innovation activities in different phases of multiple innovations. The second main contribution of our study is the need to foster interaction. Instead of focusing purely on the innovation process or matrix structure, there could be efficient action platforms combining both and simultaneously increasing interaction needed in current and future innovation activities - like in our case the innovation agent group bringing people together from different units. Often presented IT solutions can be good aid, but they alone cannot solve management challenges related to human activities. The third main point in this study is allowing and supporting the change. Organization design and processes should be able to adapt to the internal and external change demands in an efficient and profitable manner. The essence lies in the fact that the change is constant in both processes and the organization, and continued compatibility should be assured. The main point is that people with the right information have to be connected to the process at the right time to share their knowledge and they have to be able to make decisions about the tasks and resources to achieve the set goals together. From today's innovation perspective, we agree with the old wisdom (Davis \& Lawrence, 1977; Ford \& Randolph, 1992; Porter et al., 1975) that a matrix cannot be just "shifted" to an existing organizational setting. Development activities with real interaction are needed to manage resources and processes in organizations. In this paper we have also presented a way to develop and reframe innovation activities by using an innovation handbook and an innovation agent group to facilitate the change. Researchers and firms having similar challenges can further refine this approach for their tailored development activities - single case studies create value for those with similar interests (Pålshaugen, 2009).

\section{Limitations and Future Research Implications}

We note some limitations, which in turn offer opportunities for additional work. First, our results are based on a single case study on a firm having its own culture and prior structures for innovation, and thus more research is needed to ensure the generalization of the results. Moreover, some of our simplifications take a rather linear process departure to highlight the outcomes in certain stages (e.g., Table 2), but in reality the innovation process is a complex intertwined entity with multiple cycles and connections - innovations are built on innovations (Berkhout, Hartmann, Van der Duin, \& Ortt, 2006). Our research also points out the challenge of studying continuously changing matters, such as organization structures and innovation activities related to dynamic impacts of the business environment. We assume that we have managed the challenge well with a combination of various methods of data acquisition, but more can be learned with later observation and evaluation of development effects and organic change in the case organization and their relationship with unpredictable business environment change. There is an opportunity for future research to study the longitudinal managerial role of an innovation agent group and how it can develop matrix-like integration over unit borders. Another interesting aspect is how product and process innovations have an impact on organizational designs and organizational innovations in collaborative organizations and how they trigger new innovations for customers. 


\section{Conclusions}

Rapidly developing technologies and customer demands are forcing organizations towards constant change. The pressure of competition will force firms to focus on how they trim and integrate their networked innovation process and knowledge refinement according to the constant change. The temporal fit of the organizational structure and the paths for information processing have to match. Regardless of whether the organizational structure is the result of a clear management strategy or a given space for organic formation, the routes of fostering ideas to finished products or services have to be clear, efficient and seamless paths fitting the current form and operational activities of an organization. Firms would benefit if they had a general description of the innovation process and supportive functions, like they have in many quality related issues demanded by related standards and policies. They should also focus on the fuzzy front end of innovation and not only on R\&D pipes or production, as is usually the case. These descriptions should be updated to support real life actions for the current status and accepted across the organization. Assuming information flows and affecting actions is not enough, but a too stiff description is not the purpose. A compatible organizational structure and the innovation process have to be agile and adjustable based on the needs of the changing business environment.

\section{References}

Alegre, J., \& Chiva, R. (2008). Assessing the impact of organizational learning capability on product innovation performance: An empirical test. Technovation, 28(6), 315-326.

Artto, K., Kulvik, I., Poskela, J., \& Turkulainen, V. (2011). The integrative role of the project management office in the front end of innovation. International Journal of Project Management, 29(4), 408-421

Augsdörfer, P., Bessant, J., Möselin, K., Stamm, B., \& Piller, F. (2013). Discontinuous innovation - Learning to manage the unexpected. London: Imperial College Press.

Berkhout, A. J., Hartmann, D., Van der Duin, P., \& Ortt, R. (2006). Innovating the innovation process. International Journal of Technology Management, 34(3), 390-404.

Bessant, J. (2003). High-involvement innovation: Building and sustaining competitive advantage trough continuous change. Chichester: John Wiley \& Sons.

Blomqvist, K. (2002). Partnering in the dynamic environment: The role of trust in asymmetric technology partnership formation. Doctoral dissertation, Acta Universitatis Lappeenrantanensis 122, Lappeenranta University of Technology. Lappeenranta.

Burns, L., \& Wholey, D. (1993). Adoption and abandonment of matrix management programs: Effects of organizational characteristics and interoganizational networks. Academy of Management Journal, $36(1), 106-138$.

Burt, R. (2004). Structural holes and good ideas. American Journal of Sociology, 110(2), 349-399.

Camisón, C., \& Villar-López, A. (2014). Organizational innovation as an enabler of technological innovation capabilities and firm performance. Journal of Business Research, 67(1), 2891-2902.

Campos, C. (2009). How to organize for a multimedia world. In C. Erbesen, J Giner, J. Senor, \& M. Torres (Eds.), Innovations in newspapers world report 2009. A report of the Innovation International Media Consulting Group.

Candi, M., Van den Ende, J., \& Gemser, G. (2013). Organizing innovation projects under technological turbulence. Technovation, 33(4-5), 133-141.

Carleton, T. (2010). The value of vision in radical technological innovation. Doctoral dissertation, Stanford University, Palo Alto, CA.

Chesbrough, H. (2003). Open innovation: The new imperative for creating and profiting from technology. Boston: Harvard Business School Press. 
Interaction and Innovation - Reframing Innovation Activities for a Matrix Organization

Cooper, R. G. (1990). Stage-gate systems: A new tool for managing new products. Business Horizons, 33(3), 44-54.

Cooper, R. G. (1993). Winning at new products: Accelerating the process from idea to launch. Cambridge, Mass: Addison-Wesley.

Coughlan, P., \& Coghlan, D. (2002). Action research for operations management. International Journal of Operations \& Production Management, 22(2), 220-240.

Davis, S., \& Lawrence, P. (1977). Matrix. Massachusetts: Addison-Wesley.

Dougherty, D. (2008). Bridging social constraint and social action to design organizations for innovation. Organization Studies, 29(3), 415-434.

Eisenhardt, K. M. (1989). Building theories from case study research. The Academy of Management Review, 14(4), 532-550.

Ellonen, R., Blomqvist, K., \& Puumalainen, K. (2008). The role of trust in organisational innovativeness. European Journal of Innovation Management, 11(2), 160-181.

Fjeldstad, Ø., Snow, C., Miles, R., \& Lettl, C. (2012). The architecture of collaboration. Strategic Management Journal, 33(6), 734-750.

Flyvbjerg, B. (2006). Five misunderstandings about case-study research. Qualitative Inquiry, 12(2), 219245.

Ford, R. C., \& Randolph A. W. (1992). Cross-functional structures: A review and integration of matrix organization and project management. Journal of Management, 18(2), 267-294.

Galbraith, J. R. (1971). Matrix organization designs. How to combine functional and project forms. Business Horizons, 14(1), 29-40.

Godkin, L. (2010). The zone of inertia: Absorptive capacity and organizational change. The Learning Organization, 17(3), 196-207.

Halbesleben, J. R. B., Novicevic, M., Harvey, M., \& Buckley, R. (2003). Awareness of temporal complexity in leadership of creativity and innovation: A competency-based model. The Leadership Quarterly, 14(4-5), 433-454.

Haveman, H. A. (1994). The ecological dynamics of organizational change: Density and mass dependence in rates of entry into new markets. In J. A. C. Baum \& J. V. Singh (Eds.), Evolutionary dynamics of organizations (pp. 152-167). New York: Oxford University Press.

Hobday, M. (2000). The project-based organisation: An ideal form for managing complex products and systems? Research Policy, 29(7-8), 871-893.

Huston, L., \& Sakkab, N. (2006). Connect and develop: Inside Procter \& Gamble's new model for innovation, Harvard Business Review, 84(3), 58-66.

Johannessen, J. (2009). A systemic approach to innovation: the interactive innovation model. Kybernetes $38(1 / 2), 158-176$.

Kallio, A., Kujansivu, P., \& Parjanen, S. (2012). Locating the loopholes of innovation capability before launching development project. Interdisciplinary Journal of Information, Knowledge, and Management, 7(1), 21-38. Retrieved from http://www.ijikm.org/Volume7/IJIKMv7p021-038Kallio574.pdf

Kesting, P., \& Ulhøi, J. P. (2010). Employee-driven innovation: Extending the license to foster innovation. Management Decision, 48(1), 65-84.

Liker, J. (2004). The Toyota way: 14 management principles from the world's greatest manufacturer. (1st ed.). New York: McGraw-Hill.

March, J. G. (1991). Exploration and exploitation in organizational learning. Organization Science, 2(1), 71-87.

Mee, J. F. (1964). Ideational items: Matrix organization. Business Horizons, 7(2), 70-72. 
Miles, R., Snow, C., Fjeldstad, Ø., \& Miles, G. (2010). Designing organizations to meet 21st-century opportunities and challenges. Organizational Dynamics, 39(2), 93-103.

Mintzberg, H. (1983). Structure in fives: Designing effective organizations. New Jersey: Prentice Hall International Editions.

Muthusamy, S. (2009). Organizational innovativeness: A theoretical review and integration. Working Paper Series, Bowling Green State University.

Nesheim, T. (2011). Balancing process ownership and line management in a matrix-like organization. Knowledge and Process Management, 18(2), 109-119.

Parjanen, S., Harmaakorpi, V., \& Frantsi, T. (2010). Collective creativity and brokerage functions in heavily cross-disciplined innovation processes. Interdisciplinary Journal of Information, Knowledge, and Management, 5(1), 1-21. Retrieved from http://www.ijikm.org/Volume5/IJIKMv5p001021Parjanen433.pdf

Pérez-Nordtvedt, L., Payne, T. G., Short, J. C., \& Kedia, B. L. (2008). An entrainment-based model of temporal organizational fit, misfit, and performance. Organization Science, 19(5), 785-801.

Picard, R. (Ed.) (2004). Strategic responses to media market changes. JIBS Research Report Series No. 2004-2, Jönköping: Jönköping International Business School, Media Management and Transformation Centre.

Porter, L. W., Lawler E. W., \& Hackman, J. R. (1975). Behavior in organizations. New York: McGraw Hill.

Prajogo, D. I., \& Ahmed, P. K. (2006). Relationships between innovation stimulus, innovation capacity and innovation performance. $R \& D$ Management, 36(5), 499-515.

Pålshaugen, Ø. (2009). How to generate knowledge from single case research on innovation? International Journal of Action Research, 5(3), 231-254.

Salminen, J., Saunila, M., \& Mäkimattila, M. (2011). A process for developing employee-driven innovation processes. Proceedings of the 12th International CINet Conference Continuous Innovation: Doing More with Less, Aarhus, Denmark, 11-13 September 2011.

Saunila, M., Mäkimattila, M., \& Salminen, J. (2014). Matrix structure for supporting organizational innovation capability. International Journal of Business Innovation and Research, 8(1), 20-35

Smedlund, A. (2009). Network approach to fundamental tasks in knowledge based organizations. Doctoral dissertation, Series 2009/13. Helsinki University of Technology, Helsinki.

Sonnenwald, D., \& Pierce, L. (2000). Information behavior in dynamic group work contexts: Interwoven situational awareness, dense social networks and contested collaboration in command and control. Information Processing and Management, 36(3), 461-479.

Teece, D. J. (1996). Firm organization, industrial structure, and technological innovation. Journal of Economic Behavior \& Organization, 31(2), 193-224.

Teece, D.J., Pisano, G., \& Shuen, A. (1997). Dynamic capabilities and strategic management, Strategic Management Journal, 18(7), 509-533.

Tidd, J., Bessant, J., \& Pavitt, K. (2005). Managing innovation: Integrating technological, market and organizational change (3rd ed.). Chichester: Wiley.

Tushman, M., Smith, W., Woody, R., Westermanz, G., \& O’Reilly, C. (2010). Organizational designs and innovation streams. Industrial and Corporate Change, 19(5), 1331-1366.

Uotila, T., Mäkimattila, M., Harmaakorpi, V., \& Melkas, H. (2011). Combining foresight and innovation: Developing a conceptual model. In H. Melkas \& V. Harmaakorpi (Eds.), Practice-based innovation: Insights, applications and policy implications (Chapter 3, p. 29-47). Heidelberg: Springer.

Van der Panne, G., Van Beers, C., \& Kleinknecht, A. (2003). Success and failure of innovation: A literature review. International Journal of Innovation Management, 7(3), 309-338. 
Interaction and Innovation - Reframing Innovation Activities for a Matrix Organization

Van de Ven, A., \& Poole, M. (1995). Explaining development and change in organizations. Academy of Management Review, 20(3), 510-540.

Voss, C., Tsikriktsis, N., \& Frohlich, M. (2002). Case research in operations management. International Journal of Operations \& Production Management, 22(2), 195-219.

WAN-IFRA (2009). Shaping the future of the newspaper. Analysing strategic developments and opportunities in the press. World Association of Newspapers and News Publishers. Industry Special Report August 2009.

Yin, R. (1994). Case study research. Thousand Oaks, USA: Sage Publications.

Zaltman, G., Duncan, R., \& Holbek, J. (1973). Innovations and Organizations. New York: John Wiley and Sons. 


\section{Appendix. Questionnaire Design}

Questionnaire was constructed for the themes related to organizational innovation activities. Based on literature review, 55 initial items were operationalized (see Kallio, Kujansivu \& Parjanen, 2012; Saunila, Mäkimattila \& Salminen, 2014, for further details). The items were reviewed and revised with a group of researchers in order to ensure the appropriateness of each item. This process resulted in 42 items being eliminated, and 13 remained for the final version of the questionnaire. The selected items and their background are presented in table below. For each of the 13 items utilized, the respondents were asked to indicate their opinion on a Likert-type scale ranging from 1 to 5 about the seen importance for organization and current situation in organization.

\begin{tabular}{ll}
\hline Theme and questions & Meaning for innovation activities \\
\hline INNOVATION STRUCTURES & \\
$\begin{array}{l}\text { I Ideas are systematically collected in our } \\
\text { unit }\end{array}$ & $\begin{array}{l}\text { Innovation should be supported by sufficient tools, processes and } \\
\text { systems }\end{array}$ \\
$\begin{array}{l}\text { W We have a clear way of how ideas are } \\
\text { processed and implemented }\end{array}$ & $\begin{array}{l}\text { Effective further development of ideas is necessary for the suc- } \\
\text { cess of the innovation process }\end{array}$ \\
$\begin{array}{l}\text { F get feedback for my ideas } \\
\text { for innovation }\end{array}$ \\
\hline
\end{tabular}

\section{ORGANIZATIONAL CULTURE}

4 We ensure that the reasons for problems are investigated and eliminated

It is important to modify systems and processes fairly quickly

5 Different opinions are appreciated in our organization

An organization should tolerate individuals who do things in a different way

6 Cooperation between units works well

An organization should have an effective environment for collaboration within and between departments

\section{LEADERSHIP}

7 I have the courage to try new things despite the possibility of failure

Individuals should be encouraged to try new ideas without fear of failure and its consequences

8 My ideas have an effect on our actions

Managers should increase the personnel's opportunities to participate in development activities

\section{EXPLOITATION OF EXTERNAL} KNOWLEDGE

9 I apply ideas from other fields of industry to my work

10 I interact with customers in my work

11 Customers' ideas are exploited in our unit

\section{INDIVIDUAL CREATIVITY}

12 I enjoy my work

13 I participate actively in development
Good ideas emerge by applying information from outside an organization

Interaction with customers can provide missing inputs into the learning process which the organization itself cannot provide

The ability to exploit external knowledge is a critical component of innovative capability

Internal motivation includes for example deep interest and involvement in one's work

Individuals should have an opportunity to affect the outcome of their work 


\section{Biographies}

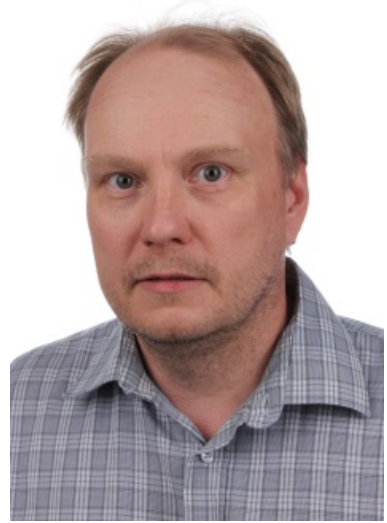

Martti Mäkimattila, M.Sc. (Tech.), M.Sc (Econ. \& Bus. Adm.) is a $\mathrm{PhD}$ student and Researcher at Lahti School of Innovation, Lappeenranta University of Technology (LUT), Finland. His research focuses on systemic innovations. Prior to joining the academic community he has gathered profound management experience in international business and R\&D contexts.

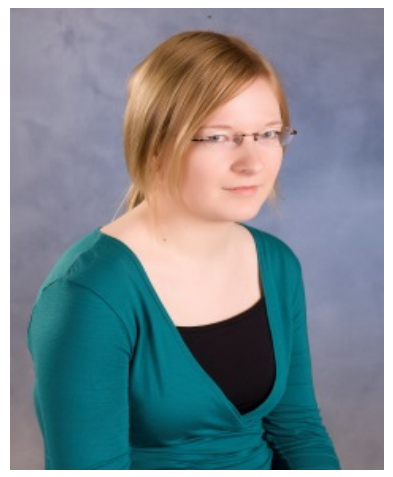

Minna Saunila is a Researcher at Lappeenranta University of Technology, Lahti School of Innovation. Her current research focuses on performance measurement and management, including the measurement of innovation capability and the relationship between innovation capability and organizational performance in small and medium sized enterprises.

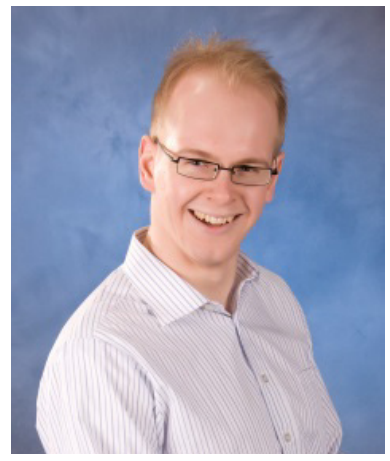

Juho Salminen is a Researcher and PhD student at Lappeenranta University of Technology, Lahti School of Innovation. Salminen is currently working in various projects related to the improvement of innovation capabilities. His personal research interests are in crowdsourcing, collective intelligence and innovation processes. 